\title{
A Comparative Assessment of the Fracture Toughness Behavior of Ferritic- Martensitic Steels and Nanostructured Ferritic Alloys
}

\author{
Thak Sang Byun ${ }^{1}$, David T. Hoelzer ${ }^{2}$, Jeoung Han Kim³ ${ }^{3}$, Stuart A. Maloy ${ }^{4}$ \\ ${ }^{1}$ Pacific Northwest National Laboratory, Richland, WA 99352, USA \\ ${ }^{2}$ Oak Ridge National Laboratory, Oak Ridge, TN 37831, USA \\ ${ }^{3}$ Hanbat National University, Daejeon 305-719, South Korea \\ ${ }^{4}$ Los Alamos National Laboratory, Los Alamos, NM 87545, USA
}

\begin{abstract}
The Fe-Cr alloys with ultrafine microstructures are primary candidate materials for advanced nuclear reactor components because of their excellent high temperature strength and high resistance to radiation-induced damage such as embrittlement and swelling. Mainly two types of $\mathrm{Fe}-\mathrm{Cr}$ alloys have been developed for the high temperature reactor applications: the quenched and tempered ferritic-martensitic (FM) steels hardened primarily by ultrafine laths and carbonitrides and the powder metallurgy-based nanostructured ferritic alloys (NFAs) by nanograin structure and nanoclusters. This study aims at elucidating the differences and similarities in the temperature and strength dependences of fracture toughness in the $\mathrm{Fe}-\mathrm{Cr}$ alloys to provide a comparative assessment of their high-temperature structural performance. The $\mathrm{K}_{\mathrm{JQ}}$ versus yield stress plots confirmed that the fracture toughness was inversely proportional to yield strength. It was found, however, that the toughness data for some NFAs were outside the band of the integrated dataset at given strength level, which indicates either a significant improvement or deterioration in mechanical properties due to fundamental changes in deformation and fracture mechanisms. When compared to the behavior of NFAs, the FM steels have shown much less strength dependence and formed narrow fracture toughness data bands at a significantly lower strength region. It appeared that at high temperatures $\geq 600 \circ \mathrm{C}$ the NFAs cannot retain the nanostructure advantage of high strength and high toughness either by high-temperature embrittlement or by excessive loss of strength. Irradiation studies have revealed, however, that the NFAs have much stronger radiation resistance than tempered
\end{abstract}


martensitic steels, such as lower radiation-induced swelling, finer helium bubble formation, lower irradiation creep rate and reduced low temperature embrittlement. 


\section{Introduction}

The iron-chromium (Fe-Cr) alloys have been developed for high-temperature reactor applications because of their high resistance to corrosion, microstructural instability, creep deformation, and radiation-induced damage. Thus far, the $\mathrm{Fe}-\mathrm{Cr}$ alloys for nuclear reactor applications have been studied primarily in two types: the melt-based ferritic-martensitic (FM) steels [1-7] and powder metallurgy-based nanostructured ferritic alloys (NFAs) [8-14]. In particular, the $\mathrm{Fe}-9 \mathrm{Cr}$ and $\mathrm{Fe}-12 \mathrm{Cr}$ ferritic-martensitic (FM) steels and $\mathrm{Fe}-9 \mathrm{Cr}$ and $\mathrm{Fe}-14 \mathrm{Cr}$ nanostructured ferritic alloys (NFAs) became primary candidate materials for various components of advanced nuclear power systems, such as the first-wall and breeding blanket structures of fusion reactors, fuel cladding and duct of fast reactors, and cladding for spallation targets in the accelerator driven systems [2-7,12-16]. In fact, some FM steels have been successfully applied to reactor core components, e.g., the HT9 steel (12Cr-MoVW steel) for the fuel cladding and duct of sodium-cooled reactors (SFRs) [7, 17-26]. For the majority of the new Fe-Cr alloys, however, any reactor core application will require a new assessment of mechanical stability in high temperature irradiation and their compatibility with the coolant at high temperatures [4-7, 15-21].

It is believed that the most important characteristics of the Fe-Cr based alloys that enable applications in such high-temperature and high-flux irradiation environments originate from their highly stable ultrafine microstructures. In general, such desirable fine microstructures with high strength can be achieved through existing processing routes with a wide range of $\mathrm{Fe}-\mathrm{Cr}$ compositions: that is, the quenched and tempered FM steels are hardened primarily by ultrafine laths and carbonitrides while the NFAs by nanograin structure and nanoclusters (or fine oxide particles) [1-3,8-13]. Many past studies have confirmed that the nanoparticles in NFAs have relatively higher stability in high temperature irradiation, and therefore they help retain nanograin structures and associated resistance to radiation-induced damage such as embrittlement and swelling [1-7, 27-34]. Although significant characterization results support possible applications of new Fe-Cr alloys in various irradiation conditions, however, some structural integrity controlling properties, such as the fracture toughness in the as-fabricated condition, need to be separately assessed because they can limit the fabrication processes of components and such baseline properties also determine much of the in-service performance [32-34].

The objective of the research was to assess the baseline mechanical properties of the $\mathrm{Fe}-\mathrm{Cr}$ alloys, focusing on the high-temperature fracture toughness behavior. A large number of fracture toughness data, including both published [7, 17-26, 30-35] and newly produced datasets, were integrated into the fracture toughness versus strength plots [37-39] and fracture toughness versus test temperature plots. These plots were designed to reveal the best 
contrasts between developed and underdeveloped materials (in NFAs, in particular) and between FM steels and NFAs, as well as to help find real drawbacks in performance and a direction for further development. Discussion is focused primarily on the four alloy systems, i.e., $9 \mathrm{Cr}$ and $12 \mathrm{Cr}$ FM steels and $9 \mathrm{Cr}$ and $14 \mathrm{Cr}$ NFAs, which are among the most frequently studied as the future nuclear reactor core materials. 


\section{Experimental}

\subsection{Materials and specimens}

Table 1 lists the two types of Fe-Cr alloys compared in the study, along with their chemistries and final thermomechanical treatments (TMTs). In the discussion the Fe-Cr alloys are categorized into four groups: $9 \mathrm{Cr}$ and $12 \mathrm{Cr}$ FM steels and $9 \mathrm{Cr}$ and $14 \mathrm{Cr}$ NFAs. As is well known, the FM steels, strengthened by fine laths and carbide particles, can be used up to about 550 으, for example, in the sodium-cooled fast reactors [7, 18-22, 25-26]. Meanwhile, during the past few decades, the NFAs, a new grade of oxide dispersion strengthened (ODS) steels, have been developed as high energy mechanical milling and high power consolidation enabled the production of the nanograin structures of high strength $\mathrm{Fe}-\mathrm{Cr}$ alloys, which are further stabilized by the high density of Y-Ti-O enriched nanoclusters [8-14, 29-36]. Primarily in the fast reactor and fusion reactor communities, the NFA developments have aimed at expanding the application capability of Fe-Cr alloys to a higher temperature region of 500-700 ㄷ.

As summarized in Table 1, all of the FM steels were tested in typical normalized and tempered conditions, while the Fe-9Cr and Fe-14Cr NFAs are in a variety of TMT conditions as they are still under development. Note that some alloys were tested in two specimen orientations: L-T and T-L orientations, where L-T means that the principal loading at crack tip is parallel to the rolling $(L)$ direction and crack propagation occurs in the transverse $(T)$ direction while T-L specifies the orientation of the $90^{\circ}$ turned specimens. If not specified, the specimens were assumed to be tested in the L-T orientation, with which specimens are generally tougher than those with the other orientation. The plots for the fracture toughness $\left(\mathrm{K}_{\mathrm{JQ}}\right)$ versus yield stress (YS) relationship [37-39] and $\mathrm{K}_{\mathrm{JQ}}$ versus temperature relationship for those types of materials aim to reveal the relative performance of these materials groups as well as the influence of processing route in NFAs. 
Table 1(a). List of high-chromium ferritic-martensitic (FM) steels compared in the study

\begin{tabular}{|c|c|c|c|c|c|}
\hline \# & Materials Identification & Nominal Chemistry & $\begin{array}{l}\text { Specimen } \\
\text { Type/Orientation }\end{array}$ & Final TMT & Ref. \# \\
\hline A1 & 9Cr-MoWVNb (NF616) & $\begin{array}{l}\text { Fe-9Cr-1.9W-0.45Mn-0.45Mo-0.2Ni- } \\
0.1 \mathrm{Nb}-0.2 \mathrm{Si}-0.1 \mathrm{C}-0.05 \mathrm{Cu}-0.011 \mathrm{~S}\end{array}$ & DCT/L-T & $\begin{array}{l}1079^{\circ} \mathrm{C} / 0.5 \mathrm{~h}+\mathrm{AC} \text { (air-cooled) \& } \\
746^{\circ} \mathrm{C} / 1 \mathrm{~h}+\mathrm{AC}\end{array}$ & \\
\hline A2 & $\begin{array}{l}\text { 9Cr-MoWVNb (NF616- } \\
\text { 1539ST) }\end{array}$ & $\begin{array}{l}\text { Fe-9Cr-1.06W-0.5Mn-0.01Mo-0.14Ta- } \\
0.25 \mathrm{Si}-0.32 \mathrm{~V}-0.109 \mathrm{C}-0.055 \mathrm{~N}\end{array}$ & DCT/L-T & $\begin{array}{l}1070^{\circ} \mathrm{C} / 0.75 \mathrm{~h}+\mathrm{AC} \& 760^{\circ} \mathrm{C} / 0.75 \\
h+A C\end{array}$ & \\
\hline A3 & $\begin{array}{l}\text { 9Cr-1MoVNb (T91-Huang } \\
\text { et al, 1992) }\end{array}$ & $\begin{array}{l}\text { Fe-8.92Cr-1.09Mo-0.39Mn-0.2V- } \\
0.07 \mathrm{Nb}-0.1 \mathrm{C}\end{array}$ & $\begin{array}{l}\text { DCT/T-L } \\
2.54 \mathrm{mmB} / 11.94 \mathrm{mmD}\end{array}$ & $1038^{\circ} \mathrm{C} / 5 \mathrm{~min}+\mathrm{AC} \& 760^{\circ} \mathrm{C} / 1 \mathrm{~h}+\mathrm{AC}$ & [18] \\
\hline A4 & $\begin{array}{l}\text { 9Cr-1MoVNb (T91-Jia et } \\
\text { al, 2006) }\end{array}$ & $\begin{array}{l}\text { Fe-8.32Cr-0.86Mo-0.48Mn-0.2V- } \\
0.15 \mathrm{Si}-0.06 \mathrm{Nb}-0.09 \mathrm{C} \text { (heat 30176) }\end{array}$ & $\begin{array}{l}\text { TPB } \\
2 \times 4 \times 20 \mathrm{~mm}\end{array}$ & $1050^{\circ} \mathrm{C} / 0.5 \mathrm{~h}+\mathrm{AC} \& 760^{\circ} \mathrm{C} / 1 \mathrm{~h}+\mathrm{AC}$ & [17] \\
\hline A5 & $\begin{array}{l}\text { 9Cr-1MoVNb (T91-Maloy } \\
\text { et al, 2001) }\end{array}$ & $\begin{array}{l}\text { Fe-9.24Cr-0.96Mo-0.47Mn-0.16Ni- } \\
.21 \mathrm{~V}-0.05 \mathrm{Nb}-0.089 \mathrm{C}\end{array}$ & DCT/L-T\&T-L & $1038^{\circ} \mathrm{C} / 1 \mathrm{~h}+\mathrm{AC} \& 760^{\circ} \mathrm{C} / 1 \mathrm{~h}+\mathrm{AC}$ & [7] \\
\hline A6 & $\begin{array}{l}\text { 9Cr-1WVTa (Eurofer-97 } \\
\text { Chaouadi et al, 2010) }\end{array}$ & $\begin{array}{l}\text { Fe-8.99Cr-1.1W-0.44Mn-0.19V-0.13Ta- } \\
0.12 \mathrm{C}\end{array}$ & $\begin{array}{l}\text { TPB } \\
6 \times 9 \times 45 \mathrm{~mm}\end{array}$ & $980^{\circ} \mathrm{C} / 27 \mathrm{~min}+\mathrm{AC} \& 760^{\circ} \mathrm{C} / 1.5 \mathrm{~h}+\mathrm{AC}$ & {$[20]$} \\
\hline B1 & $\begin{array}{l}\text { 12Cr-1MoVW (HT9-FFTF- } \\
\text { TL) }\end{array}$ & $\begin{array}{l}\text { Fe-11.87Cr-1.02Mo-0.58Mn-0.55W- } \\
0.53 \mathrm{Ni} 0.27 \mathrm{Si}-0.3 \mathrm{~V}-0.2 \mathrm{C} \text { (heat } 84425 \text { ) }\end{array}$ & $\begin{array}{l}\text { DCT/T-L } \\
2.54 \mathrm{mmB} / 11.94 \mathrm{mmD}\end{array}$ & $\begin{array}{l}1065^{\circ} \mathrm{C} / 0.5 \mathrm{~h}+\mathrm{AC} \& 750^{\circ} \mathrm{C} / 1 \mathrm{~h}+\mathrm{AC} \\
\text { (ACO-3 duct) }\end{array}$ & {$[25]$} \\
\hline B2 & $\begin{array}{l}\text { 12Cr-1MoVW (HT9-INL- } \\
\text { LT) }\end{array}$ & $\begin{array}{l}\text { Fe-12Cr-1Mo-0.6Mn-0.55W-0.5Ni- } \\
0.3 \mathrm{~V}-0.3 \mathrm{Si}-0.2 \mathrm{C}\end{array}$ & DCT/L-T & $1030^{\circ} \mathrm{C} / 0.5 \mathrm{~h}+\mathrm{AC} \& 760^{\circ} \mathrm{C} / 1 \mathrm{~h}+\mathrm{AC}$ & \\
\hline B3 & $\begin{array}{l}\text { 12Cr-1MoVW (HT9-INL- } \\
\mathrm{TL})\end{array}$ & $\begin{array}{l}\text { Fe-11.9Cr-1.0Mo-0.6Mn-0.55W-0.5Ni- } \\
0.3 \mathrm{~V}-0.3 \mathrm{Si}-0.2 \mathrm{C}\end{array}$ & $\mathrm{DCT} / \mathrm{T}-\mathrm{L}$ & $1030^{\circ} \mathrm{C} / 0.5 \mathrm{~h}+\mathrm{AC} \& 760^{\circ} \mathrm{C} / 1 \mathrm{~h}+\mathrm{AC}$ & \\
\hline B4 & $\begin{array}{l}\text { 12Cr-1MoVW (HT9-FFTF- } \\
\text { Reuse) }\end{array}$ & $\begin{array}{l}\text { Fe-11.87Cr-1.02Mo-0.58Mn-0.55W- } \\
0.53 \mathrm{Ni} 0.27 \mathrm{Si}-0.3 \mathrm{~V}-0.2 \mathrm{C}\end{array}$ & $\begin{array}{l}\text { SEB/L-T } \\
3.05 \times 4 \times 13.5 \mathrm{~mm}\end{array}$ & $\begin{array}{l}1065^{\circ} \mathrm{C} / 0.5 \mathrm{~h}+\mathrm{AC} \& 750^{\circ} \mathrm{C} / 1 \mathrm{~h}+\mathrm{AC} \\
\text { (ACO-3 duct) }\end{array}$ & {$[24,25]$} \\
\hline B5 & $\begin{array}{l}\text { 12Cr-1MoVW (HT9-FFTF- } \\
\text { Huang et al, 1984) }\end{array}$ & $\begin{array}{l}\text { Fe-11.88Cr-1.02Mo-0.50Mn-0.50W- } \\
0.58 \mathrm{Ni} 0.23 \mathrm{Si}-0.34 \mathrm{~V}-0.2 \mathrm{C} \text { (heat } 91354 \text { ) }\end{array}$ & $\begin{array}{l}\text { DCT/T-L } \\
11.9 / 32 \mathrm{~mm}\end{array}$ & $\begin{array}{l}1149^{\circ} \mathrm{C} / 1 \mathrm{~h}+\mathrm{AC} \& 740-760^{\circ} \mathrm{C} / 1 \\
\mathrm{~h}+\mathrm{AC}\end{array}$ & [19] \\
\hline B6 & $\begin{array}{l}\text { 12Cr-1MoVW (HT9-FFTF- } \\
\text { Huang et al, 1992) }\end{array}$ & $\begin{array}{l}\text { Fe-11.87Cr-1.02Mo-0.58Mn-0.55W- } \\
0.53 \mathrm{Ni} 0.27 \mathrm{Si}-0.3 \mathrm{~V}-0.2 \mathrm{C} \text { (heat } 84425 \text { ) }\end{array}$ & $\begin{array}{l}\text { DCT/T-L } \\
2.54 \mathrm{mmB} / 11.94 \mathrm{mmD}\end{array}$ & $1038^{\circ} \mathrm{C} / 5 \mathrm{~min}+\mathrm{AC} \& 760^{\circ} \mathrm{C} / 0.5 \mathrm{~h}+\mathrm{AC}$ & [18] \\
\hline
\end{tabular}

Note-1: Three-point bend (TPB) specimen: $2.5 \mathrm{~mm}$ (thickness) $\times 5 \mathrm{~mm}$ (width) $\times 15 \mathrm{~mm}$ (length) if not specified otherwise.

Note-2: Disk compact tension (DCT) specimen: 3.05-4.6 mm (thickness) $\times 12.5 \mathrm{~mm}$ (diameter) if not specified otherwise. 
Table 1(b). List of nanostructured ferritic alloys (NFAs) compared in the study

\begin{tabular}{|c|c|c|c|c|c|}
\hline$\#$ & Materials Identification & Nominal Chemistry & $\begin{array}{l}\text { Specimen } \\
\text { Type/Orientati } \\
\text { on }\end{array}$ & Final TMT & $\begin{array}{l}\text { Ref. } \\
\#\end{array}$ \\
\hline A1 & $\begin{array}{l}\text { 9Cr NFA (9YWTV-PM1- } \\
\text { Extruded) }\end{array}$ & $\begin{array}{l}\mathrm{Fe}-8.94 \mathrm{Cr}-1.98 \mathrm{~W}-0.35 \mathrm{Ti}- \\
0 ., 18 \mathrm{~V}-0.11 \mathrm{C}-0.3 \mathrm{Y}_{2} \mathrm{O}_{3}\end{array}$ & TPB/L-T & Extruded at $<850^{\circ} \mathrm{C}$ & [33] \\
\hline A2 & $\begin{array}{l}\text { 9Cr NFA (9YWTV-PM2- } \\
\text { Extruded) }\end{array}$ & $\begin{array}{l}\text { Fe-8.91Cr-1.98W-0.37Ti- } \\
0.18 \mathrm{~V}-0.06 \mathrm{C}-0.3 \mathrm{Y}_{2} \mathrm{O}_{3}\end{array}$ & TPB/L-T & Extruded at $<850^{\circ} \mathrm{C}$ & [33] \\
\hline A3 & $\begin{array}{l}\text { 9Cr NFA (9YWTV-PM1-900 } \\
\text { to } 1000^{\circ} \mathrm{C} \text { Rolled) }\end{array}$ & $\begin{array}{l}\text { Fe-8.94Cr-1.98W-0.35Ti- } \\
0 ., 18 \mathrm{~V}-0.11 \mathrm{C}-0.3 \mathrm{Y}_{2} \mathrm{O}_{3}\end{array}$ & TPB/L-T & $\begin{array}{l}\text { Extruded at }<850^{\circ} \mathrm{C} \text {, hot-rolled at } 900-1000^{\circ} \mathrm{C} \text { for } 50 \% \\
\text { reduction }\end{array}$ & $\begin{array}{l}{[33,} \\
34]\end{array}$ \\
\hline A4 & $\begin{array}{l}\text { 9Cr NFA (9YWTV-PM2-900 } \\
\text { to } 950^{\circ} \mathrm{C} \text { Rolled) }\end{array}$ & $\begin{array}{l}\text { Fe-8.91Cr-1.98W-0.37Ti- } \\
0.18 \mathrm{~V}-0.06 \mathrm{C}-0.3 \mathrm{Y}_{2} \mathrm{O}_{3}\end{array}$ & TPB/L-T & $\begin{array}{l}\text { Extruded at }<850^{\circ} \mathrm{C} \text {, hot-rolled at } 900-950^{\circ} \mathrm{C} \text { for } 50 \% \\
\text { reduction }\end{array}$ & $\begin{array}{l}{[33,} \\
34]\end{array}$ \\
\hline A5 & $\begin{array}{l}\text { 9Cr NFA (9YWTV-PM2-975 } \\
\text { to } 1000^{\circ} \mathrm{C} \text { Rolled) }\end{array}$ & $\begin{array}{l}\mathrm{Fe}-8.91 \mathrm{Cr}-1.98 \mathrm{~W}-0.37 \mathrm{Ti}- \\
0.18 \mathrm{~V}-0.06 \mathrm{C}-0.3 \mathrm{Y}_{2} \mathrm{O}_{3}\end{array}$ & TPB/L-T & $\begin{array}{l}\text { Extruded at }<850^{\circ} \mathrm{C} \text {, hot-rolled at } 975-1000^{\circ} \mathrm{C} \text { for } 50 \% \\
\text { reduction }\end{array}$ & $\begin{array}{l}{[33,} \\
34]\end{array}$ \\
\hline A6 & $\begin{array}{l}\text { 9Cr NFA (9YWTV-PM2S-900 } \\
\text { to } 950^{\circ} \mathrm{C} \text { Rolled) }\end{array}$ & $\begin{array}{l}\mathrm{Fe}-9.06 \mathrm{Cr}-2.0 \mathrm{~W}-0.36 \mathrm{Ti}- \\
0.18 \mathrm{~V}-0.05 \mathrm{C}-0.3 \mathrm{Y}_{2} \mathrm{O}_{3}\end{array}$ & TPB/T-L & $\begin{array}{l}\text { Extruded at }<850^{\circ} \mathrm{C} \text {, hot-rolled at } 900-950^{\circ} \mathrm{C} \text { for } 50 \% \\
\text { reduction }\end{array}$ & $\begin{array}{l}{[33,} \\
34]\end{array}$ \\
\hline A7 & 9Cr NFA (LAF3C) & $\begin{array}{l}\text { Fe-8.6Cr-2.0W-0.44Mn- } \\
0.24 \mathrm{Si}-0.29 \mathrm{~V}-0.065 \mathrm{C}- \\
0.08 \mathrm{Ta}-1.0\left(\mathrm{Y}_{2} \mathrm{O}_{3}+\mathrm{TiO}_{2}\right)\end{array}$ & TPB/L-T & $\begin{array}{l}\text { 1:1 oxide ratio }\left(\mathrm{TiO}_{2} / \mathrm{Y}_{2} \mathrm{O}_{3}\right), 16: 1 \text { reduction extrusion at } \\
1150^{\circ} \mathrm{C}, 1050^{\circ} \mathrm{C} / 1 \mathrm{~h}+\mathrm{AC} \& 750^{\circ} \mathrm{C} / 1 \mathrm{~h}+\mathrm{AC}[36]\end{array}$ & \\
\hline A8 & 9Cr NFA (LAF20) & $\begin{array}{l}\mathrm{Fe}-8.6 \mathrm{Cr}-2.0 \mathrm{~W}-0.44 \mathrm{Mn}- \\
0.24 \mathrm{Si}-0.29 \mathrm{~V}-0.065 \mathrm{C}- \\
0.08 \mathrm{Ta}-1\left(\mathrm{Y}_{2} \mathrm{O}_{3}+\mathrm{TiO}_{2}\right)\end{array}$ & TPB/L-T & $\begin{array}{l}2: 1 \text { oxide ratio, } 16: 1 \text { reduction extrusion at } 1150^{\circ} \mathrm{C} \text {, } \\
1050^{\circ} \mathrm{C} / 1 \mathrm{~h}+\mathrm{AC} \& 750^{\circ} \mathrm{C} / 1 \mathrm{~h}+\mathrm{AC}[36]\end{array}$ & \\
\hline A9 & 9Cr ODS (Eurofer-97) & $\begin{array}{l}\text { Fe-9Cr-1W-0.4Mn-0.2V- } \\
0.1 \mathrm{Si}-0.1 \mathrm{Ta}-0.07 \mathrm{C}+0.3 \mathrm{Y}_{2} \mathrm{O}_{3}\end{array}$ & TPB/L-T & $\begin{array}{l}\text { Consolidated by HIP, hot-rolled at } 1150^{\circ} \mathrm{C} \text {, Quenched (from } \\
\left.1100^{\circ} \mathrm{C} 30 \mathrm{~min}\right) \text { and Tempered }\left(750^{\circ} \mathrm{C}\right) .\end{array}$ & \\
\hline A10 & $\begin{array}{l}\text { 9Cr ODS (Eurofer-97, } \\
\text { McClintock et al, 2009) }\end{array}$ & $\begin{array}{l}\text { Fe-9Cr-1W-0.4Mn-0.2V- } \\
0.1 \mathrm{Si}-0.1 \mathrm{Ta}-0.07 \mathrm{C}+0.3 \mathrm{Y}_{2} \mathrm{O}_{3}\end{array}$ & $\begin{array}{l}\text { TPB/L-T } \\
2 \times 4 \times 20 \mathrm{~mm}\end{array}$ & $\begin{array}{l}\text { Consolidated by HIP, hot-rolled at } 1150^{\circ} \mathrm{C} \text {, Quenched (from } \\
1100^{\circ} \mathrm{C} 30 \mathrm{~min} \text { ) and Tempered }\left(750^{\circ} \mathrm{C}\right) .\end{array}$ & [30] \\
\hline B1 & 14Cr NFA (14YWT-SM10) & $\mathrm{Fe}-14 \mathrm{Cr}-3 \mathrm{~W}-0.4 \mathrm{Ti}-0.3 \mathrm{Y}_{2} \mathrm{O}_{3}$ & DCT/L-T & $\begin{array}{l}\text { Extruded at } 850^{\circ} \mathrm{C} \text {, annealed at } 1000^{\circ} \mathrm{C} \text { for } 1 \mathrm{hr} \text {, hot-rolled } \\
\text { at } 850^{\circ} \mathrm{C} \text { for } 40 \% \text { reduction. }\end{array}$ & [31] \\
\hline B2 & $\begin{array}{l}\text { 14Cr NFA (14YWT-SM11- } \\
\text { Rolled) }\end{array}$ & Fe-14Cr-3W-0.4Ti-0.3 $\mathrm{Y}_{2} \mathrm{O}_{3}$ & DCT/L-T & $\begin{array}{l}\text { Extruded at } 850^{\circ} \mathrm{C} \text {, annealed at } 1000^{\circ} \mathrm{C} \text { for } 1 \mathrm{hr} \text {, hot-rolled } \\
\text { at } 1000^{\circ} \mathrm{C} \text { for } 40 \% \text { reduction. }\end{array}$ & \\
\hline B3 & $\begin{array}{l}\text { 14Cr NFA (14YWT-SM12- } \\
850 \& 850^{\circ} \mathrm{C} \text { Extruded-LT) }\end{array}$ & $\mathrm{Fe}-14 \mathrm{Cr}-3 \mathrm{~W}-0.4 \mathrm{Ti}-0.3 \mathrm{Y}_{2} \mathrm{O}_{3}$ & TPB/L-T & $\begin{array}{l}\text { Annealed at } 850^{\circ} \mathrm{C} / 1 \mathrm{~h} \text {, extruded at } 850^{\circ} \mathrm{C} / 1 \mathrm{~h} \text {, hot-rolled } \\
\text { (normal to extrusion direction) at } 1000^{\circ} \mathrm{C} \text { for } 50 \% \\
\text { reduction. }\end{array}$ & [32] \\
\hline
\end{tabular}




\begin{tabular}{|c|c|c|c|c|c|}
\hline B4 & $\begin{array}{l}\text { 14Cr NFA (14YWT-SM12- } \\
850 \& 850^{\circ} \mathrm{C} \text { Extruded-TL) }\end{array}$ & Fe-14Cr-3W-0.4Ti- $0.3 \mathrm{Y}_{2} \mathrm{O}_{3}$ & TPB/T-L & $\begin{array}{l}\text { Annealed at } 850^{\circ} \mathrm{C} / 1 \mathrm{~h} \text {, extruded at } 850^{\circ} \mathrm{C} / 1 \mathrm{~h} \text {, hot-rolled } \\
\text { (normal to extrusion direction) at } 1000^{\circ} \mathrm{C} \text { for } 50 \% \\
\text { reduction. }\end{array}$ & [32] \\
\hline B5 & $\begin{array}{l}\text { 14Cr NFA (14YWT-SM12- } \\
850 \& 1000^{\circ} \mathrm{C} \text { Extruded-LT) }\end{array}$ & Fe-14Cr-3W-0.4Ti- $0.3 \mathrm{Y}_{2} \mathrm{O}_{3}$ & TPB/L-T & $\begin{array}{l}\text { Annealed at } 850^{\circ} \mathrm{C} / 1 \mathrm{~h} \text {, extruded at } 1000^{\circ} \mathrm{C} / 1 \mathrm{~h} \text {, hot-rolled } \\
\text { (normal to extrusion direction) at } 1000^{\circ} \mathrm{C} \text { for } 50 \% \\
\text { reduction. }\end{array}$ & [32] \\
\hline B6 & $\begin{array}{l}\text { 14Cr NFA (14YWT-SM12- } \\
850 \& 1000^{\circ} \mathrm{C} \text { Extruded-TL) }\end{array}$ & Fe-14Cr-3W-0.4Ti- $0.3 \mathrm{Y}_{2} \mathrm{O}_{3}$ & TPB/T-L & $\begin{array}{l}\text { Annealed at } 850^{\circ} \mathrm{C} / 1 \mathrm{~h} \text {, extruded at } 1000^{\circ} \mathrm{C} / 1 \mathrm{~h} \text {, hot-rolled } \\
\text { (normal to extrusion direction) at } 1000^{\circ} \mathrm{C} \text { for } 50 \% \\
\text { reduction. }\end{array}$ & [32] \\
\hline B7 & $\begin{array}{l}\text { 14Cr NFA (14YWT-SM12- } \\
850 \& 1150^{\circ} \mathrm{C} \text { Extruded-LT) }\end{array}$ & $\mathrm{Fe}-14 \mathrm{Cr}-3 \mathrm{~W}-0.4 \mathrm{Ti}-0.3 \mathrm{Y}_{2} \mathrm{O}_{3}$ & TPB/L-T & $\begin{array}{l}\text { Annealed at } 850^{\circ} \mathrm{C} / 1 \mathrm{~h} \text {, extruded at } 1150^{\circ} \mathrm{C} / 1 \mathrm{~h} \text {, hot-rolled } \\
\text { (normal to extrusion direction) at } 1000^{\circ} \mathrm{C} \text { for } 50 \% \\
\text { reduction. }\end{array}$ & [32] \\
\hline B8 & $\begin{array}{l}\text { 14Cr NFA (14YWT-SM12- } \\
850 \& 1150^{\circ} \mathrm{C} \text { Extruded-TL) }\end{array}$ & $\mathrm{Fe}-14 \mathrm{Cr}-3 \mathrm{~W}-0.4 \mathrm{Ti}-0.3 \mathrm{Y}_{2} \mathrm{O}_{3}$ & TPB/T-L & $\begin{array}{l}\text { Annealed at } 850^{\circ} \mathrm{C} / 1 \mathrm{~h} \text {, extruded at } 1150^{\circ} \mathrm{C} / 1 \mathrm{~h} \text {, hot-rolled } \\
\text { (normal to extrusion direction) at } 1000^{\circ} \mathrm{C} \text { for } 50 \% \\
\text { reduction. }\end{array}$ & [32] \\
\hline B9 & $\begin{array}{l}\text { 14Cr NFA (14YWT-Milled at } \\
\text { RT) }\end{array}$ & $\mathrm{Fe}-14 \mathrm{Cr}-3 \mathrm{~W}-0.4 \mathrm{Ti}-0.3 \mathrm{Y}_{2} \mathrm{O}_{3}$ & TPB/L-T & $\begin{array}{l}\text { Consolidated by } \mathrm{HIP} \text { at } 1150^{\circ} \mathrm{C} \text {, hot-rolled at } 1100^{\circ} \mathrm{C} \text { for } \\
50 \% \text { reduction. }\end{array}$ & [35] \\
\hline B10 & $\begin{array}{l}\text { 14Cr NFA (14YWT- } \\
\left.\text { Cryomilled at }-75^{\circ} \mathrm{C}\right)\end{array}$ & Fe-14Cr-3W-0.4Ti-0.3Y ${ }_{2} \mathrm{O}_{3}$ & TPB/L-T & $\begin{array}{l}\text { Consolidated by } \mathrm{HIP} \text { at } 1150^{\circ} \mathrm{C} \text {, hot-rolled at } 1100^{\circ} \mathrm{C} \text { for } \\
50 \% \text { reduction. }\end{array}$ & [35] \\
\hline B11 & $\begin{array}{l}\text { 14Cr NFA (14YWT- } \\
\left.\text { Cryomilled at }-150^{\circ} \mathrm{C}\right)\end{array}$ & $\mathrm{Fe}-14 \mathrm{Cr}-3 \mathrm{~W}-0.1 \mathrm{Ti}-0.3 \mathrm{Y}_{2} \mathrm{O}_{3}$ & TPB/L-T & $\begin{array}{l}\text { Consolidated by } \mathrm{HIP} \text { at } 1150^{\circ} \mathrm{C} \text {, hot-rolled at } 1100^{\circ} \mathrm{C} \text { for } \\
50 \% \text { reduction. }\end{array}$ & [35] \\
\hline B12 & 14Cr NFA (14YWT-NFA1-LT) & Fe-14Cr-3W-0.4Ti- $0.3 \mathrm{Y}_{2} \mathrm{O}_{3}$ & $\begin{array}{l}\text { Square CT/L-T } \\
2.5 \times 12.5 \times 12.5 \\
\mathrm{~mm}\end{array}$ & $\begin{array}{l}\text { Extruded at } 850^{\circ} \mathrm{C} \text {, annealed at } 1000^{\circ} \mathrm{C} \text { for } 1 \mathrm{hr} \text {, hot-rolled } \\
\text { at } 1000^{\circ} \mathrm{C} \text { for } 50 \% \text { reduction. }\end{array}$ & \\
\hline B13 & 14Cr NFA (14YWT-NFA1-TL) & $\mathrm{Fe}-14 \mathrm{Cr}-3 \mathrm{~W}-0.4 \mathrm{Ti}-0.3 \mathrm{Y}_{2} \mathrm{O}_{3}$ & $\begin{array}{l}\text { Square } \mathrm{CT} / \mathrm{T}-\mathrm{L} \\
2.5 \times 12.5 \times 12.5 \\
\mathrm{~mm}\end{array}$ & $\begin{array}{l}\text { Extruded at } 850^{\circ} \mathrm{C} \text {, annealed at } 1000^{\circ} \mathrm{C} \text { for } 1 \mathrm{hr} \text {, hot-rolled } \\
\text { at } 1000^{\circ} \mathrm{C} \text { for } 50 \% \text { reduction. }\end{array}$ & \\
\hline B14 & $\begin{array}{l}\text { 14Cr NFA (14YWT-SM6, } \\
\text { McClintock et al, 2009) }\end{array}$ & $\mathrm{Fe}-14 \mathrm{Cr}-3 \mathrm{~W}-0.4 \mathrm{Ti}-0.3 \mathrm{Y}_{2} \mathrm{O}_{3}$ & $\begin{array}{l}\text { TPB/L-T } \\
2 \times 4 \times 20 \mathrm{~mm}\end{array}$ & $\begin{array}{l}\text { Extruded at } 850^{\circ} \mathrm{C} \text {, annealed at } 1000^{\circ} \mathrm{C} \text { for } 1 \mathrm{hr} \text {, hot-rolled } \\
\text { at } 850^{\circ} \mathrm{C} \text { for } 40 \% \text { reduction. }\end{array}$ & [30] \\
\hline
\end{tabular}

Note-1: Three-point bend (TPB) specimen: $2.5 \mathrm{~mm}$ (thickness) $\times 5 \mathrm{~mm}$ (width) $\times 15 \mathrm{~mm}$ (length) if not specified otherwise.

Note-2: Disk compact tension (DCT) specimen: 3.05-4.6 mm (thickness) $\times 12.5 \mathrm{~mm}$ (diameter) if not specified otherwise. 


\subsection{Static fracture toughness testing}

Static fracture resistance (J-R) tests have been carried out using either $15 \mathrm{~mm}$ long threepoint bend (TPB) specimens, $12.5 \mathrm{~mm}$ diameter disk compact tension (DCT), or $12.5 \times 12.5 \mathrm{~mm}$ CT specimens if performed by the authors. These are highly miniaturized specimens and the fracture testing at high temperatures using such miniature specimens requires a simplified testing technique and accordingly modified toughness calculation procedure. A streamlined testing and analysis procedure consisting of precracking, static fracture testing in controlled environments, and construction of J-R curves have been established for efficient testing of such miniaturized specimens [23-25, 31-35, 40]. Since the standard unloading compliance method for crack extension measurement described in ASTM E1820 [41] becomes highly inaccurate in the J-R testing at high temperatures using miniature specimens, the curve normalization method, which is described in the annex of the same standard method, had to be used for the testing campaign. The main simplification made in the experimental procedure was removing the external displacement (clip) gage that is usually attached to the fracture specimen. That is, no externally attached gage was used in both precracking and static J-R testing. Further, the J-R curve calculation procedure was also modified in accordance with the configuration without attached gage. In the modified procedure the plastic displacement component was extracted and used for calculating plastic J-integral value and the elastic J-integral component was theoretically calculated form the measured load and specimen dimension data [41]. On the other hand, the fracture toughness data from the past studies were obtained through appropriate procedures at those times and some data were recalculated to comply with the current ASTM standard [17-19].

A signal comparison technique developed for miniaturized fracture testing in controlled environments [40] was used for the fatigue-precracking of the TPB and (D)CT specimens. In the fatigue mode, the cyclic load is usually applied to the notched specimen in a load-control mode, in which the load amplitude, frequency, and median value are constant. However, the amplitude and median value of displacement reading from the embedded linear variable differential transducer will change to accommodate the specimen flexibility increasing with crack growth. Both of those changes in cyclic displacement signal can be used to measure crack growth amount, typically at an accuracy of $0.1 \mathrm{~mm}$. Precracking for the miniature specimens was performed at a cyclic load of (500 to $700 \mathrm{~N}) \pm(450$ to $600 \mathrm{~N})$ at 20 or $30 \mathrm{~Hz}$, depending on the mechanical properties and geometry of specimens. Typically, an increase of $3-5 \%$ in displacement amplitude or $30-50 \%$ shift in the median value of a displacement cycle was required for a 0.7-1 $\mathrm{mm}$ fatigue crack growth in the miniature specimens or an appropriate crack length-to-width ration $(a / w)$ of $0.42-0.5$. The final step of precracking was to apply 
significant cycles $(10,000$ or more) at a reduced (at least $50 \%$ ) load level from the initial load to guarantee the high sharpness of crack tip.

Fracture resistance ( $\mathrm{J}-\mathrm{R}$ ) tests in (quasi) static mode were performed in compressive loading mode for TPB specimens and tensile mode for (D)CT specimens at a displacement rate of 0.005 $\mathrm{mm} / \mathrm{s}$ in a servohydraulic test frame. The test frame was equipped with a resistance heating furnace that has capabilities of temperature control within $\pm 1{ }^{\circ} \mathrm{C}$ operated in either vacuum or argon environment. The static fracture testing and evaluation were performed following the standard procedure described by the ASTM Standard E1820. Since the curve normalization method (E1820 Appendix [41]) was used in the construction of fracture resistance (J-R) curves, the monotonic load-displacement curve data were recorded during testing. The fracture tests showing stable crack growth were stopped when the applied load decreases to about $55 \%$ of the maximum load in that test, which aimed to produce 1-2 $\mathrm{mm}$ stable crack growth in the miniature specimens. The J-R tested specimens were either fatigue-loaded in air or heat-tinted at $300{ }^{\circ} \mathrm{C}$ to make the fracture surface formed by stable crack growth discernable from the other crack surfaces before the complete separation. The initial and final crack lengths were then measured on optical fractographs and used for construction of J-R curves using the curve normalization method [41].

\section{Results and discussion}

Typically, the fracture toughness of an alloy is reduced by some strengthening means such as cold work, precipitation, and irradiation. It is therefore often observed that the fracture toughness within a materials group is inversely proportional to strength [37-39]. Such an inversely proportional toughness-strength relationship can be established when the variation in processing route for an alloy does not substantially change its fundamental properties such as grain boundary bonding, alloy composition, constituent phases, and stacking fault energy. Any significant changes in these might fundamentally alter deformation and fracture behavior in alloys. A fracture toughness-strength relationship established for an alloy group can be, therefore, used as a criterion for improvement in materials development. That is, we may have to change some of these fundamental properties to induce 'true' improvement in an alloy, which will result in having fracture toughness data in the upper and/or right side of the data band of unimproved alloys in a fracture toughness-strength plot. In the following discussion, therefore, the fracture toughness data are plotted against corresponding yield stress data (i) to reveal any true improvement for each materials group and (ii) to elucidate the effect of other factors such as test temperature and specimen orientation. In addition, the fracture toughness 
data will be replotted to display and compare the temperature dependences of the alloy groups.

\subsection{Fracture toughness versus strength behavior of NFAs in low-temperature region}

The processing of NFAs includes steps of gas atomization process for alloy powder production, mechanical milling of alloy powder, consolidation of milled powder, and additional thermomechanical treatments [11-13, 32, 33]. The behavior of final product can vary drastically with the processing route and quality control in each step. In particular, the powder metallurgybased process usually has a high tendency for producing contaminated or overly hardened boundaries in the final product, and those boundaries may lead to an easy failure initiation and consequential low fracture toughness [33]. Therefore, compared to the toughness versus strength behavior of the melt-based FM steels typically in quenched and tempered conditions, the NFAs are expected to show wider variation in their behavior.

Figure 1 displays the strength-toughness relationship of various $9 \mathrm{Cr}$ and $14 \mathrm{Cr}$ NFA groups. It is noted that all of the data presented in Figure 1 have been obtained in the relatively low temperature region, $22-300{ }^{\circ} \mathrm{C}$, where most ferritic or ferritic-martensitic steels show little temperature dependence in strength. A dotted red line is also drawn at $100 \mathrm{MPaVm}$ level to indicate a minimum fracture toughness value that might be required for an engineering application. This fracture toughness might be a good bench mark value to test the minimum fabricability of metallic materials. It is shown in Figure 1 that the majority of fracture toughness-yield strength data belong to the central main band (in the sky blue shadow), which clearly show an inversely proportional strength-toughness relationship. It seems that the main band can describe the inversely proportional relationship over wide ranges of yield strength (800-2200 MPa) and fracture toughness (10-280 MPaVm).

It is also observed in Figure 1 that some specially-treated NFA groups have yielded islands of datasets which stand out separately from the main trend band. There are three groups of NFAs whose data points are in the right side of the major band, which indicates an improved property compared to those in the major band. The scattered fracture toughness-yield stress data of 9Cr NFA (9YWT-PM2) in hot-rolled conditions [33, 34] form a small high strength-high toughness area within 1100-1500 MPa and 210-270 MPaVm. Further, the two 14Cr NFAs processed by cryogenic milling [35] or treated for a fine grain structure [31] show significant improvement in strength-toughness relationship. Meanwhile, the two groups of data are observed in the left side of the main trend band or in the relatively inferior property region: this shows that both the T-L orientation and the low energy milling can result in poor fracture toughness, mostly below the $100 \mathrm{MPaVm}$ mark, regardless of the strength spreading in a wide range of 200-1100 $\mathrm{MPa}$. 


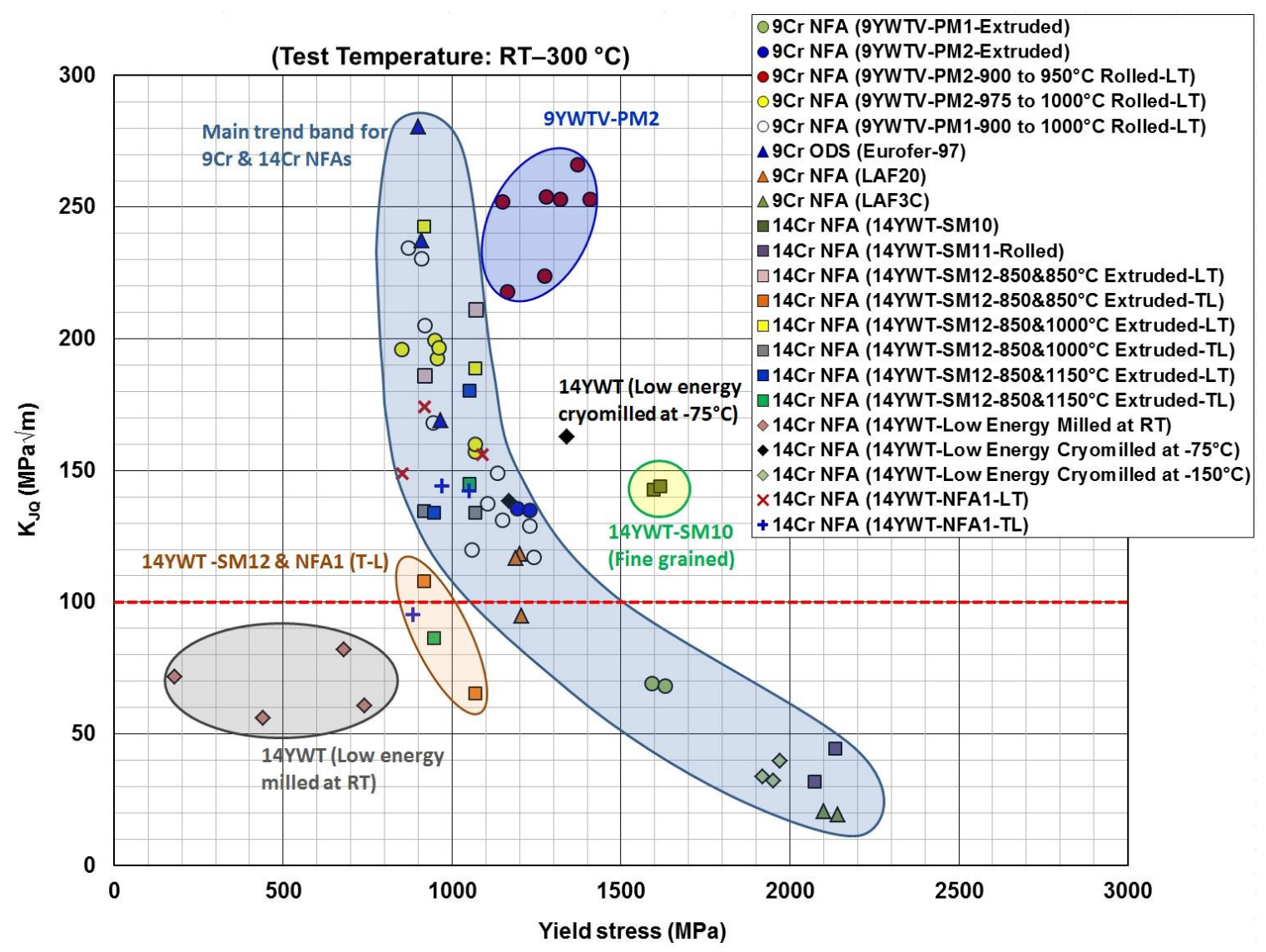

Figure 1. Fracture toughness versus yield stress plot for the $9 \mathrm{Cr}$ and $14 \mathrm{Cr}$ NFAs tested in a low temperature region of $22-300{ }^{\circ} \mathrm{C}$.

\subsection{Fracture toughness versus strength behavior of NFAs in high-temperature region}

A typical temperature dependence of fracture roughness observed in the ferritic and ferritic-martensitic steels in pristine condition is that the fracture toughness increases with temperature until it reaches an upper shelf level and slowly decreases with temperature, primarily due to decrease in strength. It is observed that the decrease of fracture toughness occurring typically above $200-300^{\circ} \mathrm{C}$ is more significant in NFAs than the behavior in high chromium FM steels. As displayed in Figure 2, therefore, the setback of the toughness versus strength data band toward the low strength-low toughness area is substantial in the higher temperature range. Consequently, many fracture toughness data $\left(\mathrm{K}_{\mathrm{Ja}}\right)$ obtained at $500-600{ }^{\circ} \mathrm{C}$ 
are located below the $100 \mathrm{MPaVm}$ mark in the plot. The fracture toughness consistently higher than this criterion was measured only for a few materials including the ODS Eurofer-97, 9YWYVPM2, and 14YWT-SM12 after specially designed TMTs.

It is worth noting that the high-temperature TMTs used for the 9YWTV-PM2 and 14YWTSM12 have been developed to improve fracture toughness [32-34]. In the past, a very high strength could only be achieved in NFAs at the expense of fracture toughness and ductility, and it was shown that a low energy decohesion at boundaries caused poor fracture resistance in NFAs at high temperatures [31-33]. Improving grain boundary bonding might be an effective method for avoiding such low energy decohesion or low fracture toughness. In the latest studies, therefore, the powder metallurgy-produced weak boundaries were strengthened by enhanced diffusion bonding during the newly designed TMTs such as controlled extrusion and multirolling processes [32-34]. Improvement of fracture toughness was significant in the hot-rolled 9YWTV-PM2 and multiple-extruded 14YWT-SM12; their fracture toughness values were as high as those of FM steels. In particular, the 9YWTV-PM2 controlled-rolled at $900{ }^{\circ} \mathrm{C}$ resulted in the best fracture toughness among NFAs, i.e., $>150 \mathrm{MPa} \sqrt{ } \mathrm{m}$ over a wide temperature range of $22-700{ }^{\circ} \mathrm{C}$. It is also worth mentioning that the low temperature $\left(900{ }^{\circ} \mathrm{C}\right)$ processing has prevented the nanograins and nanoclusters in NFAs from growing during the rigorous TMTs and resulted in such significant improvement in fracture toughness while retaining high strength. 


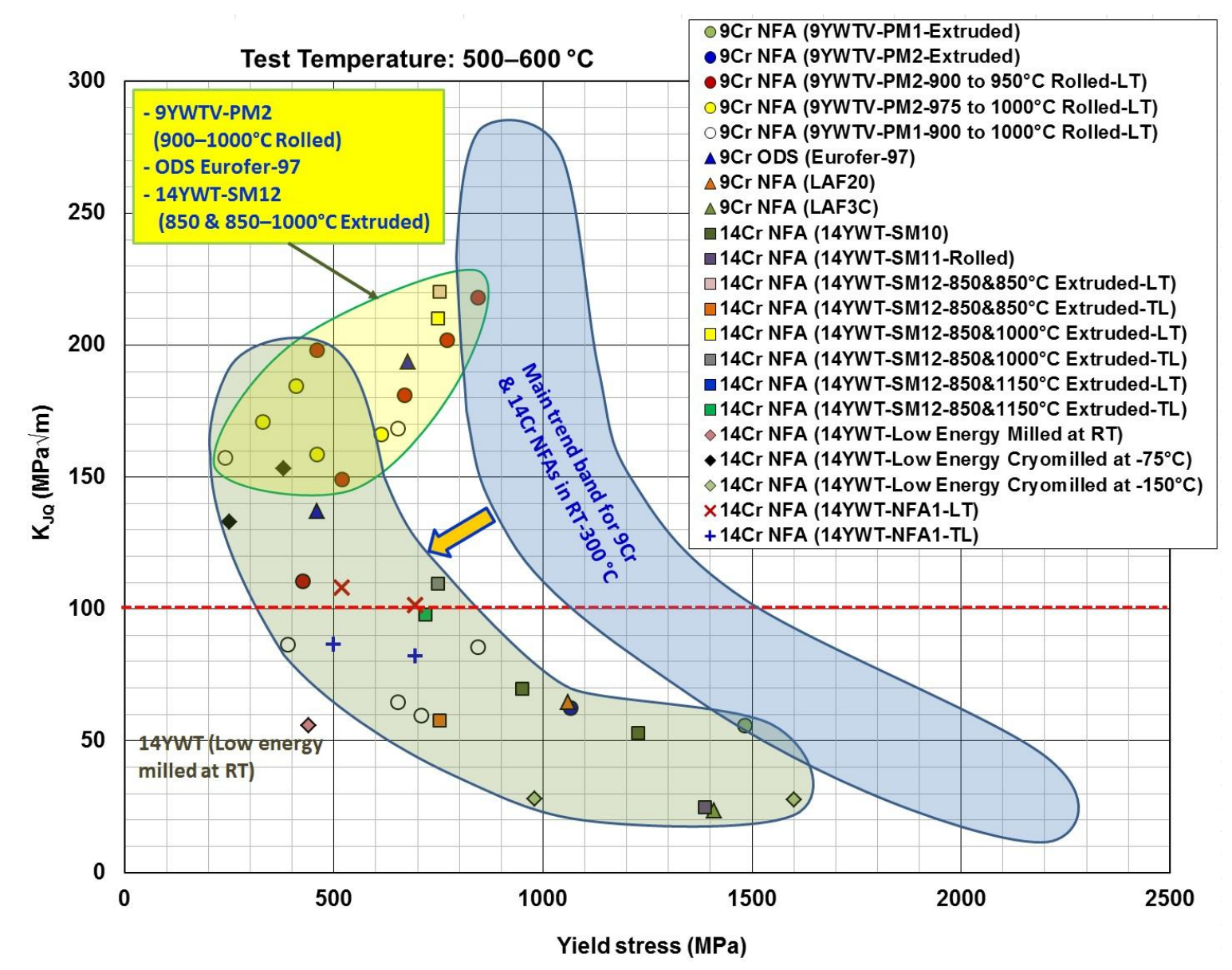

Figure 2. Fracture toughness versus yield stress plot for the $9 \mathrm{Cr}$ and $14 \mathrm{Cr}$ NFAs tested in a high temperature region of $500-600{ }^{\circ} \mathrm{C}$.

\subsection{Fracture toughness versus strength behavior of FM steels}

Figure 3 compares the fracture toughness versus yield strength relationships of FM steels (FMS) for low and high temperatures. The shadowed band for the fracture toughness of NFAs in the low temperature region is also given together for comparison. It is clearly shown that the strength dependence of fracture toughness is very weak in FM steels, and as a result both of the data bands are nearly vertical. Typical FM steel has a ductile-brittle transition region and an upper shelf region around the room temperature, above which the fracture toughness slowly decreases with test temperature [25]. Such a gradual decrease of fracture toughness with test temperature above room temperature is confirmed by the observation that the two nearly vertical bands, respectively for low and high temperature regions, are so close that those data 
bands have significant overlap. It is also worth noting that the fracture toughness data for all Fe-Cr steels remain above the $100 \mathrm{MPaVm}$ mark, except for just one data point for HT9 steel tested at $650^{\circ} \mathrm{C}$.

If compared to the high fracture toughness (> $120 \mathrm{MPaVm}$ ) portion of the band for NFAs, the low temperature band for FM steels (marked as FMS-low T) is shifted towards a lower strength region by approximately $400 \mathrm{MPa}$. For NFAs, this can be interpreted as a significant improvement of a mechanical property, primarily due to the change from melt-based process to powder metallurgy-based process. It is notable that in the low temperature region, such amount of strengthening could be made for some NFAs without sacrificing fracture toughness. It needs to be considered, however, that the superior strength of NFAs has resulted in a significant loss of ductility, and thus, possibly fabricability in the low temperature region. Regardless of the high resistances to creep deformation and radiation-induced damage found in NFAs, the poor fabricability of the alloys has become the biggest obstacle for application as structure materials [34]. 


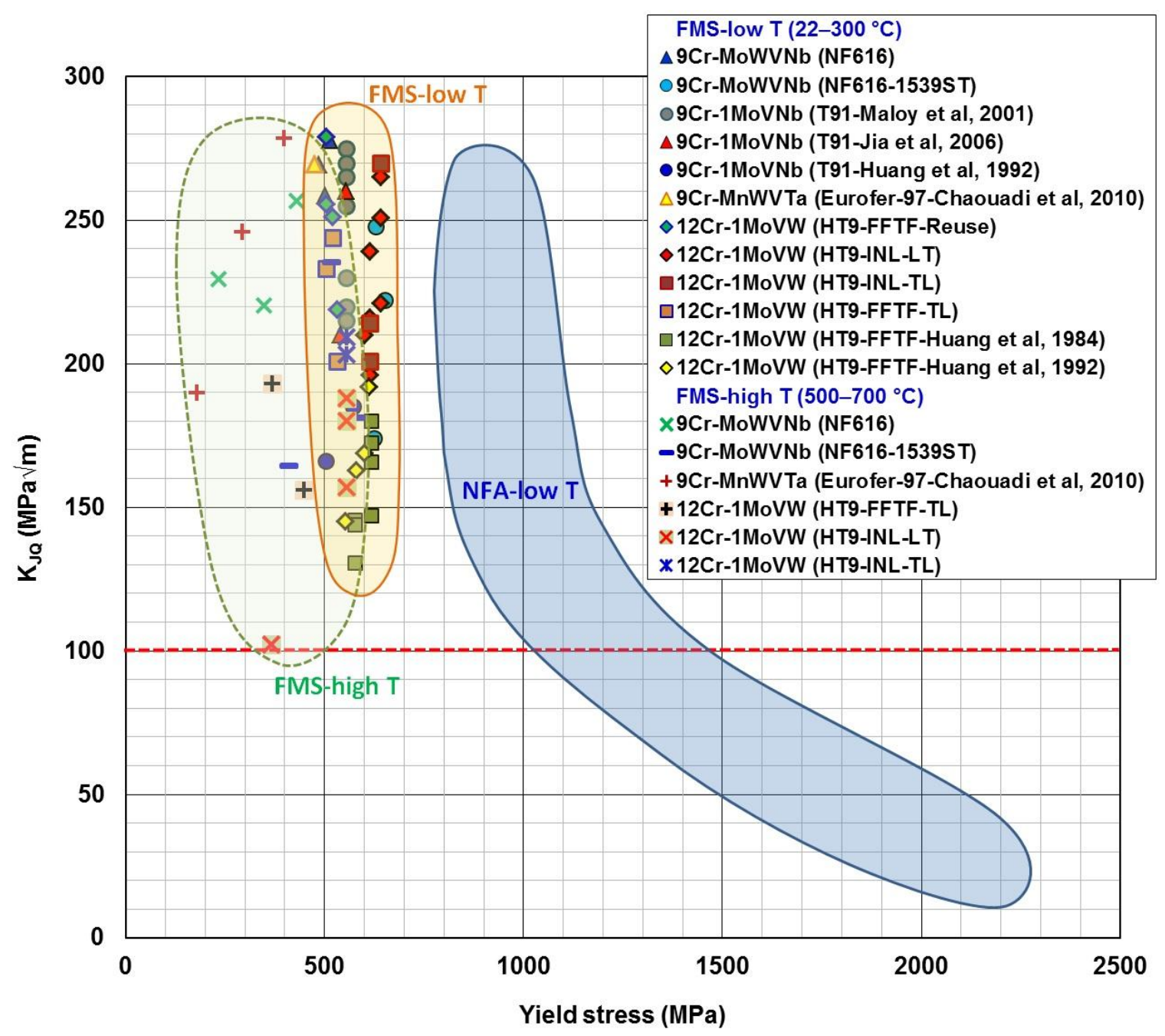

Figure 3. Fracture toughness versus yield stress plot for the 2.25-12Cr ferritic-martensitic steels tested in low-temperature $\left(22-300^{\circ} \mathrm{C}\right)$ and high-temperature $\left(500-600{ }^{\circ} \mathrm{C}\right)$ regions.

\subsection{Temperature dependence of fracture toughness in NFAs and FM steels}

The temperature dependences of fracture toughness in a variety of $8-12 \mathrm{Cr}$ ferriticmartensitic steels are integrated in Figure 4. As seen in the low temperature region of the shadowed area, a steep and well-defined ductile-to-brittle transition is a unique behavior of body centered cubic (bcc) metallic materials [22, 25, 26, 30, 42]. Indeed, the temperature transition in each pristine $\mathrm{FM}$ steel occurs within a narrow temperature range of $150{ }^{\circ} \mathrm{C}$. The peak fracture toughness is generally obtained in the range of $-100{ }^{\circ} \mathrm{C}$ to room temperature. The 
peak values often form a plateau, or an upper shelf region, and sometimes the upper shelf region can extend above room temperature.

As a temperature-transition index parameter, the temperature at which the median fracture toughness is $100 \mathrm{MPaVm}$ (with scaling to a $25 \mathrm{~mm}$ thick specimen) is defined as the reference temperature $\left(=\mathrm{T}_{0}\right)[43,44]$. In the transition region, the $\mathrm{T}_{0}$ values of the vast majority of the engineering grade $\mathrm{FM}$ steels are in the range $-120^{\circ} \mathrm{C}$ to $-50{ }^{\circ} \mathrm{C}$ and typically reach their upper shelf values at or below room temperature [22, 25, 26, 30, 42]. Figure 4 shows that the reference temperatures of FM steels measured at $100 \mathrm{MPaVm}$ are between $-150{ }^{\circ} \mathrm{C}$ and $-50^{\circ} \mathrm{C}$ without size effect scaling [42].

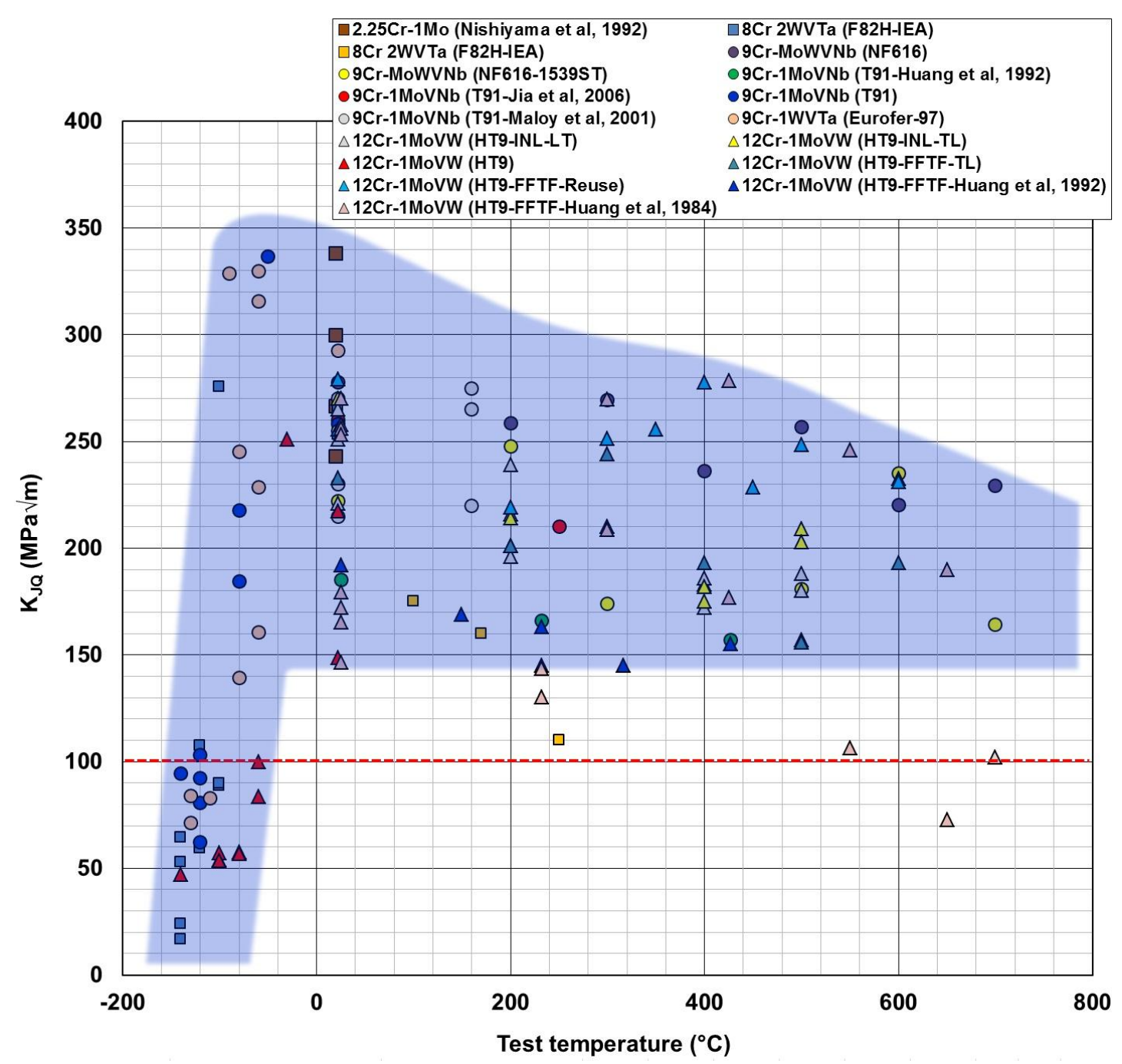

Figure 4. Temperature dependence of fracture toughness in the $9 \mathrm{Cr}$ and12Cr ferritic-martensitic steels tested in the range of -140 to $700{ }^{\circ} \mathrm{C}$. 
Above the upper shelf temperature region, the fracture toughness of FM steels slowly decreases with test temperature. In detail, however, a steep decrease or sometimes a local minimum is found in the elevated temperature region of 200 to $400{ }^{\circ} \mathrm{C}$. Such a loss of fracture toughness in the elevated temperature region is known as the effect of dynamic strain aging (DSA) due to the obstruction of dislocation glide by the cloud of interstitial elements such as nitrogen and carbon that follow the stress fields of moving dislocations [44]. As shown in Figure 4 , the DSA effect is observed in some FM steels, but the reduction of fracture toughness is less significant when compared to that of carbon steels [25, 45-47]. Comparing the fracture toughness data from high dose specimens, neutron irradiation is believed to further mitigate the DSA effect [23-25]. It can be judged therefore that the mild DSA effect in FM steels will not raise any structural integrity issue in fabrication and reactor service.

Figure 5 displays the temperature dependence of fracture toughness in a variety of $9 \mathrm{Cr}$ and $14 \mathrm{Cr}$ NFAs, in which the blue shadow for enveloping the fracture toughness data of FM steels in Figure 4 is overlaid for comparison. There are a few differences in the fracture toughness behaviors of NFAs and FM steels. First, the fracture toughness data of NFAs display very large variations among the alloys. This might be due to the large variation in alloy control and processing route since no standard specification for production and quality control has been established for the alloys. Second, some $9 \mathrm{Cr}$ and $14 \mathrm{Cr}$ NFAs have fracture toughness as

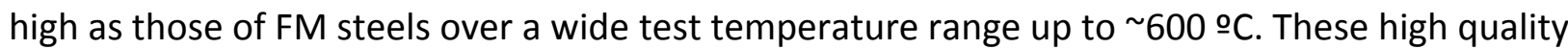
NFAs are commonly associated with specially developed TMT routes and with tight control of light elements that might have removed weakly bonded grain boundaries [32-34]. Third, the ductile-brittle transition temperatures seem to be similar to or lower than those of FM steels. It was shown that in NFAs dislocation glide was highly active in deformation, and dimple-forming ductile fracture was predominant at liquid nitrogen temperature, where the grain boundary pileup of dislocations has relatively smaller role in strain hardening and thus the stress concentration at grain boundaries can be maintained below a critical level for separation [34]. The latest hardening mechanism studies [48-51] have also confirmed that the dominance of matrix hardening or intrinsic lattice hardening at cryogenic temperatures helps avoid the grain boundary decohesion mechanism that usually is the main cause for the low toughness in the high temperature region. Fourth, the decrease of fracture toughness at elevated temperatures or DSA effect is not obvious. This lack of DSA effect might be associated with the unique nanostructure of NFAs, in which the characteristic jerky dislocation glide in the DSA process is probably not effective because of the short gliding distance. Fifth, the fracture toughness of many NFAs is either retained at low levels or significantly reduced at elevated and high temperatures while the fracture toughness of FM steels decreases gradually with temperature, 
mainly due to strength decrease, but is still retained above 140 MPaVm. This difference in the temperature dependence of some NFAs and FM steels is known to result from the difference in the grain boundary characteristics of the powder metallurgy-based NFAs and melt-based FM steels [31]. A series of studies on high temperature deformation and fracture mechanisms using 14YWT NFA have shown that microcracks tend to initiate and propagate along grain boundaries or grain aggregate boundaries by a low energy boundary decohesion mechanism, resulting in little plastic deformation in grains and thus low fracture toughness [31, 35]. It was also shown that the low toughness characteristics of the nanograin alloys, which originated from weaklybonded grain boundaries, was exacerbated at high temperatures as the grain boundary hardening became the major load-bearing component [48-51]. The stress concentration due to the dislocation pileups at grain boundaries, which is the main feature in grain boundary hardening mechanism, can force to open the weakly-bonded grain boundaries at high temperatures.

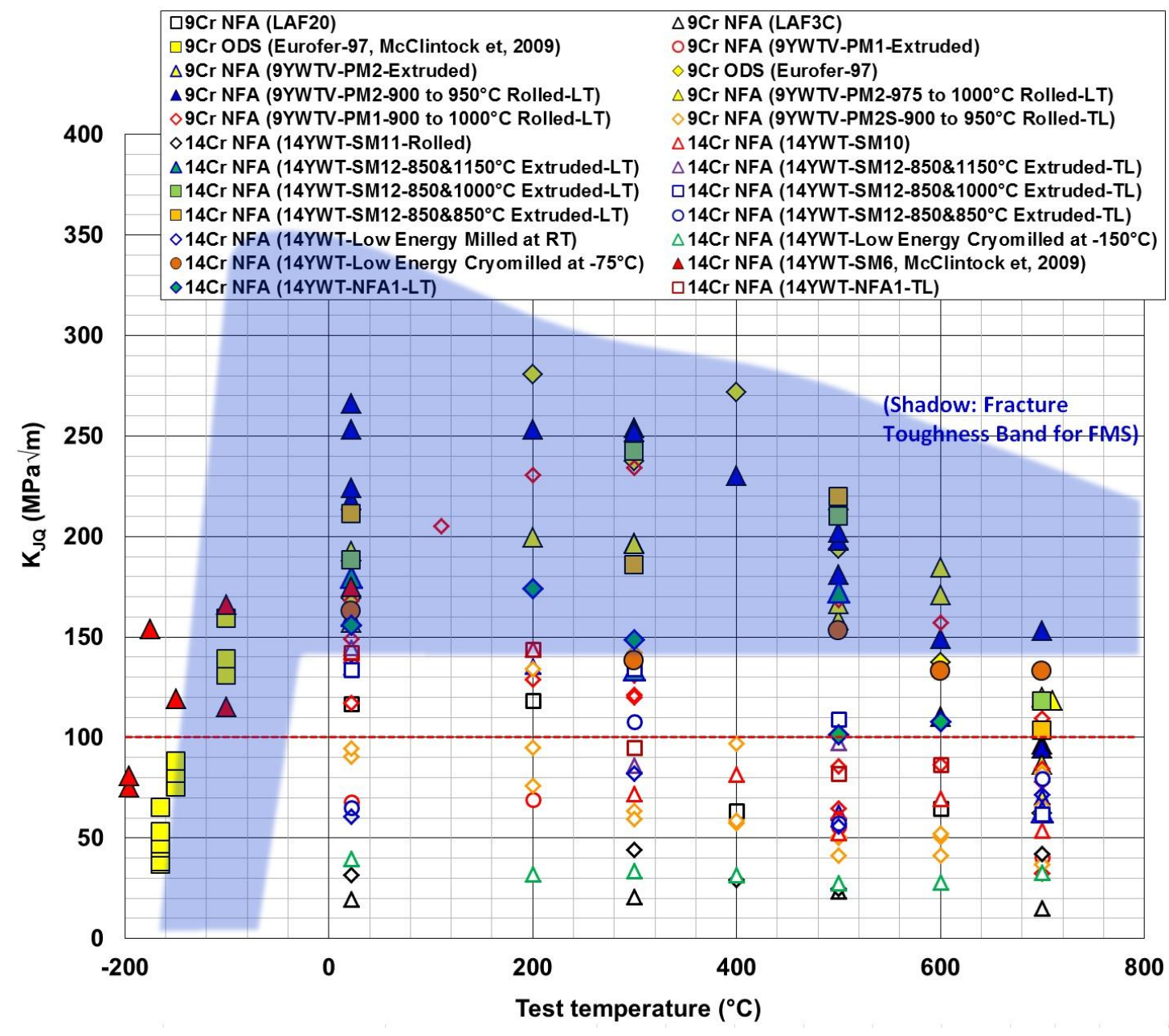


Figure 5. Temperature dependence of fracture toughness in the NFAs tested in the range of -196 to $700{ }^{\circ} \mathrm{C}$.

\subsection{Temperature dependence of yield stress}

The yield stress datasets used in the fracture toughness versus strength plots as in Figures 1 to 3 are reintegrated in Figure 6 as functions of test temperature. Both the FM steels and the NFAs retain nearly constant strength over the temperature range of room temperature to

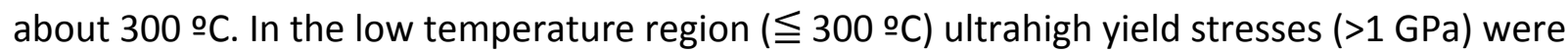
measured for the majority of NFAs [48]. In particular, two alloys (i.e., 9Cr NFA LAP3C and 14Cr NFA 14YWT-SM11) demonstrated extra high strengths above $2 \mathrm{GPa}$ at room temperature. Above $300 \circ \mathrm{C}$ the yield stress of both FM steels and NFAs decreases with temperature. The NFAs with relatively higher low-temperature strength show steeper decrease of strength above

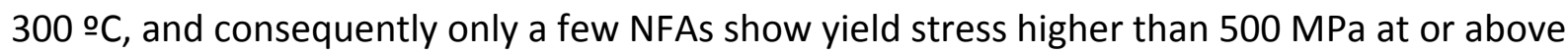
$600 \stackrel{\circ}{\circ}$.

Over the temperature range up to $700 \stackrel{\circ}{\circ}$ the band width of yield stress for FM steels is much narrower when compared with that of NFAs. In the low temperature range ( $\leqq 300 \cong \mathrm{C})$, in particular, all yield stress data for FM steels fall within a narrow range of 450-800 MPa. In the higher temperature range, on the other hand, the yield stress of FM steels gradually decreases

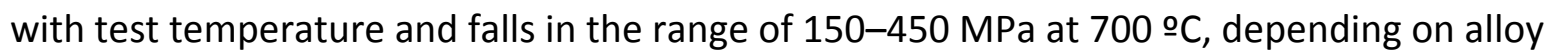
group. Despite the two Fe-Cr alloys had vastly different strength ranges in the low temperature region up to $300{ }^{\circ} \mathrm{C}$, the difference became much smaller at higher temperatures. The latest studies on the hardening mechanism in NFAs indicate that the nanoclusters in NFAs are not strong obstacles to dislocation glide even if they are thermally stable [49-51], which might limit the strengthening capability at high temperatures where the grain boundary and dislocation forest hardening become less effective.

Except for a few very hard NFAs, the yield stress datasets of FM steels and NFAs fall within the same range at or above 600 ㄷ. Indeed, only two 9Cr NFAs (LAF3C and 9YWTV-PM1 in asextruded condition) and two 14Cr NFAs (14YWT-SM10 \& SM11) have yield stresses above 500 $\mathrm{MPa}$ at $700{ }^{\circ} \mathrm{C}$, whereas the other NFAs have similar level of yield stress as that for FM steels. The yield stress range is well within 100-500 MPa range for both the FM steels and the NFAs with good fracture toughness. It is noted, however, that those strongest NFAs are also the low toughness materials as indicated in Figures 1 and 2 . It is also worth noting that the modified $9 \mathrm{Cr}$ steel NF616 [52] shows particularly high strength among the FM steels in the high temperature region: the NF616-1538ST is a Ta and V doped $9 \mathrm{Cr}$ steel with fine $(\mathrm{Ta}, \mathrm{V}) \mathrm{C}$ precipitates and was specifically designed to gain strength at high temperatures. It should be therefore recognized as 
an issue that above 600 으 the NFAs can retain strength and fracture toughness only at levels comparable with those of some advanced FM steels.

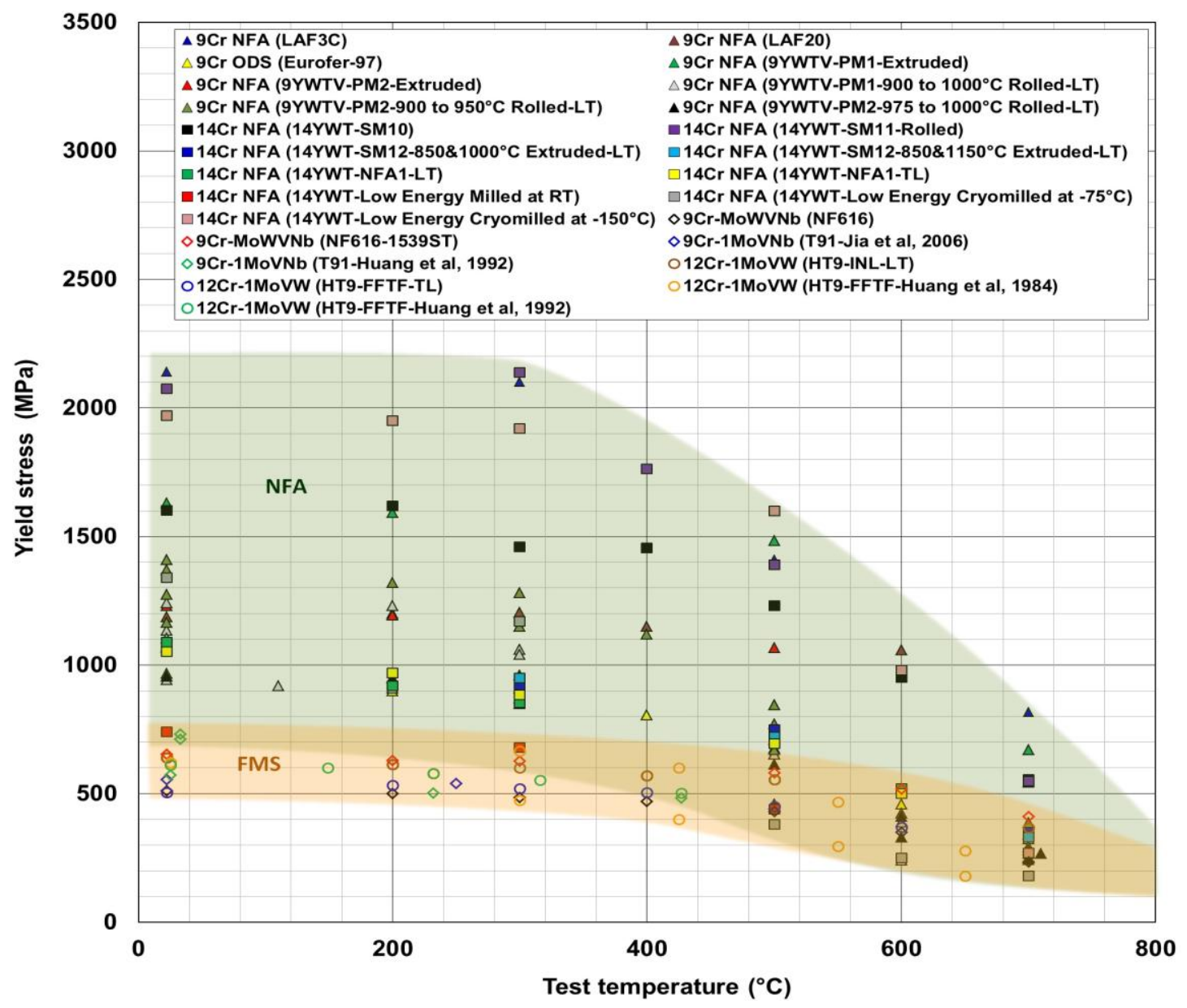

Figure 6. Temperature dependence of yield stress in ferritic-martensitic steels and nanostructured ferritic alloys.

\subsection{Further consideration for high-temperature reactor applications}

Over the past few decades, the Fe-Cr alloys have been developed to improve in-reactor performance particularly in high temperature and high dose core environments [1-7, 53-56]. The data comparison made in the previous sections might lead to an overall conclusion that a few of NFAs, if the best processing practices are taken, can achieve the high temperature fracture toughness and tensile strength that are comparable to or higher than those of the FM steels. In fact, such good mechanical properties alone, while they are desirable for component design, may not justify the application of obviously expensive NFAs to the prospective fast and 
fusion reactors. With the essential mechanical properties that can be achieved through improved control of processing, actual in-reactor performance might depend more on other high temperature behaviors such as thermal and irradiation creep, void and helium swelling, and compatibility with coolant or corrosion resistance, etc. Recent studies [53-61] show that the NFAs have generally greater advantages of nanostructures in creep, swelling, and embrittlement behaviors over the normalized (and quenched) and tempered FM steels, although only limited property data for in-reactor performance are available. Such outstanding performance in high-temperature irradiation conditions is known to result from the presence of an ultrahigh density of $\mathrm{Y}-\mathrm{Ti}-\mathrm{O}$ rich nanoparticles, fine grain sizes in submicron range, and high dislocation densities [53].

Mainly because of the thermally stable nanoparticles that can act as obstacles to grain growth, grain boundary sliding, and dislocation glide and climb, any NFA with a well-controlled nanostructure is expected to deliver high resistance to radiation damage at high temperatures. Indeed, grain boundaries and nanoparticle-matrix interfaces act as effective traps for helium and result in the formation of tiny, high-pressure gas bubbles at their interface with the matrix $[3,53-56]$. It is also found that the presence of such tiny helium bubbles formed at nanoclusters provide additional irradiation tolerance because they act as stable sink-recombination sites that self-heal excess vacancy and self-interstitial displacement damage defects [53]. Therefore, the helium atoms trapped at the high density interfaces as small bubbles, in addition to those at grain boundaries, eliminate or greatly retard rapid void swelling. In general, finer microstructures will induce less void swelling during high temperature irradiations [57]. The FM steels with fine tempered martensitic structures (HT9 and T91) typically develop much less swelling than austenitic steels during neutron or ion irradiation, sometimes by a factor of ten or more [57]. Further, the NFA MA957 with a nanostructure demonstrated significantly higher resistance to void swelling, when compared to the FM steels: swelling reached a maximum value of only $4.5 \%$ at 500 displacements per atom (dpa) in $450{ }^{\circ} \mathrm{C}$ irradiation $[28,58]$. For a duplex-structured NFA, the finer phase constituent turned out to be more effective in suppression of void swelling: the swelling in the tempered martensite with fine laths and particles is an order of magnitude less than that in the ferrite phase with a much simpler substructure [59].

Irradiation creep is another main cause for dimensional instability and possible failure during irradiation. Although the advantage of using NFAs over the traditional FM steels is yet to be conclusive because the long-term or high dose irradiation creep data are very rare for NFAs $[28,60,61]$, the superior thermal creep resistance of NFAs $[2,3,62]$ is expected to result in higher resistance to irradiation creep, which consists of thermal creep, radiation-induced creep, and irradiation-stimulated growth components. An irradiation creep and swelling study was 
performed using pressurized tubing constructed from the old NFA MA957 [28, 60], in which the miniature pressurized creep tubes were irradiated in the Fast Flux Test Facility (FFTF) to doses ranging from 40 to $110 \mathrm{dpa}$ at $400-750{ }^{\circ} \mathrm{C}$. The diametral strains after irradiation exhibited primary (transient) creep behavior, in which the total creep strain increased with stress and irradiation temperature [60]. The primary creep was followed by a steady-state creep running at a temperature-independent rate of $\sim 0.75 \times 10^{-6} /(\mathrm{MPa} \cdot \mathrm{dpa})$, which is a value similar to that of traditional tempered ferritic-martensitic steels [60]. Since the MA956 is an old NFA with relatively low density of nanoparticles, it is believed that the next generation NFAs (e.g., 14YWT and 9YWTV) with a high particle density of $\sim 10^{24} / \mathrm{m}^{3}$ should show stronger resistance to irradiation creep.

\section{Concluding remarks}

(1) The fracture toughness versus strength plots revealed well-contrasted performances among

Fe-Cr alloys, particularly in nanostructured ferritic alloys. The plots for the major groups of data have confirmed there is an inversely proportional fracture toughness-strength relationship.

(2) Only a few NFAs including 9YWTV-PM2 and 14YWT-SM12 with proper TMTs and ODS Eurofer-97 could demonstrate promising high-temperature fracture performance. The NFAs generally have an advantage of lower DBTT but some suffer a steep decrease in fracture toughness with temperature at above $500^{\circ} \mathrm{C}$, which strongly varies among different NFAs.

(3) The vast majority of FM steels have sufficient fracture toughness (> $100 \mathrm{MPaVm}$ ) over a wide temperature range of $\mathrm{RT}-700 \stackrel{\mathrm{O}}{\mathrm{C}}$, and the datasets in the low and high temperature ranges form weak fracture toughness-strength relationships within narrow strength ranges.

(4) Except for a few NFAs with ultrahigh strength (> 1.5 GPa at RT) and relatively low toughness, the yield stress data of FM steels and NFAs fell within the same range at or above

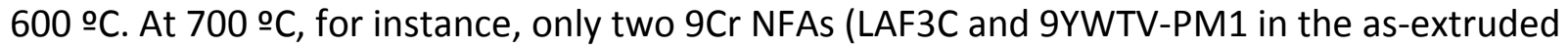
condition) and two 14Cr NFAs (14YWT-SM10 \& SM11) have yield stresses above 500 MPa, while the yield stresses of other NFAs fall within similar yield stress range as that for FM steels, i.e., 100-500 MPa.

(5) The integrated fracture toughness-strength data indicate that the overall mechanical performance of NFAs at or above 600 ㅇ $\mathrm{C}$ will be similar to that of FM steels. To provide comparatively better structural performance, the high temperature strength of NFAs needs to be further increased without losing fracture toughness. 
(6) Significant variation in properties are observed for NFAs but with improved control of impurities during processing, NFAs show an improvement of strength from low temperature to $600{ }^{\circ} \mathrm{C}$ while retaining a low DBTT, toughness above $100 \mathrm{MPaVm}$ and improved radiation tolerance (e.g. resistance to void swelling and low temperature reduction in ductility and toughness). It is judged that such high radiation resistance will be the main advantage of using NFAs in high temperature reactors.

\section{Acknowledgements}

This research was sponsored by U.S. Department of Energy/Office of Nuclear Energy through Fuel Cycle R\&D Program. Pacific Northwest National Laboratory is operated by Battelle Memorial Institute for the U.S. Department of Energy under Contract No. DE-AC05-76RL01830. The authors would like to express special thanks to Drs. Mychailo Toloczko and Timothy Lach for their technical reviews and thoughtful comments.

\section{References}

[1] R.L. Klueh, A.T. Nelson, J. Nucl. Mater. 371 (2007) 37-52.

[2] R.L. Klueh, Int. Nater. Reviews, 50 (2005) 287-310.

[3] G.R. Odette, M.J. Alinger, B.D. Wirth, Annu. Rev. Mater. Res. 38 (2008) 471-503.

[4] S.J. Zinkle, S.J. Was, Acta Mater. 61 (2013) 735-758.

[5] R.W. Grimes, R.J.M. Konings, L. Edwards, Nat. Mater. 7(9) (2008) 683-85.

[6] T.R. Allen, J.T. Busby, R.L. Klueh, S.A. Maloy, M.B. Toloczko, J. of Metals, 60 (2008) 15-23.

[7] S.A. Maloy, M.R. James, G. Willcutt, W.F. Sommer, M. Sokolov, L.L. Snead, M.L. Hamilton, F. Garner, J. Nucl. Mater. 296 (2001) 119-128.

[8] S. Ukai, M. Harada, H. Okada, M. Inoue, S. Nomura, S. Shikakura, K. Asabe,T. Nishida, M. Fujiwara, J. Nucl. Mater. 204 (1993) 65-73.

[9] M.K. Miller, D.T. Hoelzer, E.A. Kenik, K.F. Russell, J. Nucl. Mater. 329-333 (2004) 338-341.

[10] S. Ukai, S. Ohtsuka, Energy Mater. 2 (2007) 26-35. 
[11] D.T. Hoelzer, J. Bentley, M.A. Sokolov, M.K. Miller, G.R. Odette, M.J. Alinger, J. Nucl. Mater. 367-370 (2007) 166-172.

[12] M.J. Alinger, G.R. Odette, D.T. Hoelzer, Acta Mater. 57 (2009) 392-406.

[13] N. Baluc, J.L. Boutard, S.L. Dudarev, M. Rieth, J. Brito Correia, B. Fournier, J. Henry, F. Legendre, T. Leguey, M. Lewandowska, R. Lindau, E. Marquis, A. Munoz, B. Radiguet, Z. Oksiuta, J. Nucl. Mater. 417 (2011) 149-153.

[14] A. Kimura, R. Kasada, N. Iwata, H. Kishimoto, C.H. Zhang, J. Isselin, P. Dou, 417 (2011) 176179.

[15] J. Van den Bosch, R.W. Bosch, D. Sapundjiev, A. Almazouzi, J. Nucl. Mater. 376 (2008) 322329.

[16] J. Van den Bosch, G. Coen, A. Almazouzi, J. Degrieck, J. Nucl. Mater. 385 (2009) 250-257.

[17] X. Jia, Y. Dai, J. Nucl. Mater. 356 (2006) 50-55.

[18] F.H. Huang, M.L. Hamilton, Journal Nucl. Mater. 187 (1992) 278-293

[19] F.H. Huang, D.E. Gelles, Engi. Frac. Mechanics, 19 (1984) 1-84.

[20] R. Chaouadi, G. Coen, L. Lucon, V. Massaut, J. Nucl. Mater. 403 (2010) 15-18.

[21] J.S. Cheon, C.B. Lee, B.O. Lee, J.P. Raison, T. Mizuno, F. Delage, J. Carmack, J. Nucl. Mater. 392 (2009) 324-330.

[22] O. Anderoglu, T.S. Byun, M.B. Toloczko, S.A. Maloy, Met. Trans. 44A (2013) 71-83.

[23] T.S. Byun, J.H. Baek, O. Anderoglu, S.A. Maloy, M.B. Toloczko, J Nucl. Mater. 449 (2014) 263-372.

[24] J.H. Baek, T.S. Byun, S.A. Maloy, M.B. Toloczko, J Nucl. Mater. 444 (2014) 206-213.

[25] T.S. Byun, M.B. Toloczko, T.A. Saleh, S.A. Maloy, J. Nucl. Mater. 432 (2013) 1-8.

[26] T.S. Byun, W. D. Lewis, M.B. Toloczko, S. A. Maloy, J Nucl. Mater. 421 (2012) 104-111.

[27] M.P. Short, D. Gaston, M. Jin, L. Shao, F.A. Garner, J. Nucl. Mater. 471 (2016) 200-207.

[28] M.B. Toloczko, D.S. Gelles, F.A. Garner, R.J. Kurtz, K. Abe, 329-333 (2004) 352-355. 
[29] D.A. McClintock, D.T. Hoelzer, M.A. Sokolov, R.K. Nanstad, J. Nucl. Mater. 386 (2009) 307311.

[30] D.A. McClintock, M.A. Sokolov, D.T. Hoelzer, R.K. Nanstad, J. Nucl. Mater. 392 (2009) 353359.

[31] T.S. Byun, J.H. Kim, J.H. Yoon, D.T. Hoelzer, J. Nucl. Mater. 407 (2010) 78-82.

[32] D.T. Hoelzer, K.A. Unocic, M.A. Sokolov, T.S. Byun, J. Nucl. Mater. 471 (2016) 251-265.

[33] T.S. Byun, J.H. Yoon, D.T. Hoelzer, Y.B. Lee, S.H. Kang, S.A. Maloy, J. Nucl. Mater. 449 (2014) 290-299.

[34] T.S. Byun, J.H. Yoon, S.H. Wee, D.T. Hoelzer, S.A. Maloy, J. Nucl. Mater. 449 (2014) 39-48.

[35] J.H. Kim, T.S. Byun, E. Shin, J.B. Seol, S. Young, N.S. Reddy, J. Alloys and Compounds, 651 (2015) 363-374.

[36] G.R. Romanoski, L.L. Snead, R.L. Klueh, D.T. Hoelzer, J. Nucl. Mater. 283-287 (2000) 642646.

[37] R.O. Ritchie, J.F. Knott, J.R. Rice, J. Mech. Phys. Solids, 21 (1973) 395-410.

[38] R. H. Jones, C. A. Lavender and M.T. Smith, Scripta Metall. 21 (1987) 1565-1570.

[39] R.O. Ritchie, Nature Mater. 10 (2011) 817-822.

[40] T.S. Byun, S.A. Maloy, J.H. Yoon, ASTM International, STP-1576 (2015), DOI: 10.1520/STP157620140017.

[41] ASTM E1820: Standard Test Method for Measurement of Fracture Toughness.

[42] A.F. Rowcliffe, J.P. Robertson, R.L. Klueh, K. Shiba, D.J. Alexander, M.L. Grossbeck, S. Jitsukawa, J. Nucl. Mater. 258-263 (1998) 1275-1279.

[43] K. Wallin, T. Planman, M. Valo, R. Rintamaa, Eng. Frac. Mech. 68 (2001) 1265-1296.

[44] ASTM E1921: Standard Test Method for Determination of Reference Temperature, $T_{0}$, for Ferritic Steels in the Transition Range.

[45] A. van den Beukel, Physica status solidi (a), 30 (1975) 197-206.

[46] C.C. Seok, K.L. Murty, Mech. Mech. Fract. 53 (2001) 23-36. 
[47] S.S. Kang, I.S. Kim, Nucl. Technol. 97 (1992) 336-343.

[48] M.E. Alam, S. Pal, K. Fields, S. Maloy, D.T. Hoelzer, G.R. Odette, Mat. Sci. Eng. A, (in press) http://dx.doi.org/10.1016/j.msea.2016.08.051.

[49] J.H. Kim, T.S. Byun, D.T. Hoelzer, J. of Nucl. Mater. 407 (2010) 143-150.

[50] J.H. Kim, T.S. Byun, D.T. Hoelzer, S.W. Kim, B.H. Lee, Mat. Sci. Eng. A, 559 (2013) 101-110.

[51] J.H. Kim, T.S. Byun, D.T. Hoelzer, C.H. Park, J.T. Yeom, J.K. Hong, Mat. Sci. Eng. A, 559 (2013) 111-118.

[52] L. Tan, T.S. Byun, Y. Katoh, L.L. Snead, Acta Mater. 71(1) (2104) 11-19.

[53] G.R. Odette, J. of Metals, 66 (2014) 2427-2441.

[54] K. Yutani, H. Kishimoto, R. Kasada, A. Kimura, J. Nucl. Mater. 367-370 (2007) 423-427.

[55] G.R. Odette and D.T. Hoelzer, J. of Metals, 62 (2010) 84-92.

[56] Y. Dai, G.R. Odette, T. Yamamoto, Comprehensive Nucl. Mater. Atlanta, GA, Elsevier, 2012.

[57] F.A Garner, M.B Toloczko, B.H Sencer, J. Nucl. Mater. 276 (2000) 123-142.

[58] M.B. Toloczko, F.A. Garner, V.N. Voyevodin, V.V. Bryk, O.V. Borodin, V.V. Melnychenko, A.S. Kalchenko, J. Nucl. Mater. 453 (2014) 323-333.

[59] T. Chen, E. Aydogan, J.G. Gigax, D. Chen, J. Wang, X. Wang, S. Ukai, F.A. Garner, L. Shao, J. Nucl. Mater. 467 (2015) 42-49.

[60] M.B. Toloczko, F.A. Garner, S.A. Maloy, J. Nucl. Mater. 428 (2012) 170-175.

[61] J. Chen, M.A. Pouchon, A. Kimura, P. Jung, W. Hoffelner, J. Nucl. Mater. 386-388 (2009) 143-146.

[62] D. Hoelzer, J.P. Shingledecker, R.L. Klueh, M.K. Miller, J. Bentley, Fusion Mater. Semiann. Prog. Rep. (2008). 